\title{
二次元電気泳動法による
} 細胞表面タンパク質の分析

今田 勝

明治乳業(株)研究所

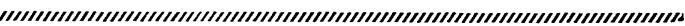

多細胞生物の形質膜の構成成分は，分泌，吸収，神経 やホルモンによる刺激伝達，細胞間認識，増殖などの諸 現象に执いて大切な役割を持つと考兄られ，その解明は 今後の大きな課題である．従来，細胞表面タンパク質の 同定法としては，O'Farrell 法 ${ }^{(3)}$ とよる二次元電気泳動法 が利用されているが，この方法では，難溶性タンパク質 がゲルに回収されなかったり，分析中に沈渐したりする ことは，筆者のみならず他の研究者も経験しているとこ ろである(4). そこで本稿では，筆者らの開発した，細胞 表面に存在するタンパク質と糖タンパク質の 分析法 ${ }^{(1,2)}$ を紹介しょう．本法の最大の特徵は，きわめて難溶性の 膜タンパク質を、ほぼ完全に可溶化した状態で分析でき ることから，分析に見逃しが少ないことである。

\section{1. 糖タンパク質の放射性標識}

細胞表面タンパク質を放射性同位元素で特異的に標識 するには，酵素を用いる方法 ${ }^{(5,6)}$ と，低分子量の標識試 薬を用いる方法(7)などがある，さらに，糖タンパク質が 主として細胞表面に局在することに注目して，放射性の 糖で細胞を標識するのる簡便法としては有效である(8). 分析材料としては，接着性の培養細胞が最適であるが， リンパ細胞や腹水癌などの浮遊細胞，さらには網膜(9)の ような摘出組織を利用することもできる。

ラクトパーオキシダーゼ法では $\left.{ }^{[125 I}\right]$ または ${ }^{1{ }^{131} I} \mathrm{I}$ $\mathrm{NaI}$ を用いてタンパク質のチロシン残基とヒスチジン 残基を修飾するが，筆者らは主として $\left[{ }^{125} \mathrm{I}\right]-\mathrm{NaI}$ を用 いている．まず細胞を直径 $35 \mathrm{~mm}$ の培養血に $0.2 \sim 2.5$ $\times 10^{5}$ 細胞 $/ \mathrm{cm}^{2}$ の密度で播き, 24 時間後に培地交換を 行ない,さらに 24 時間後に下記の 方法で 標識を行な う. 培地を除去し, 細胞を $2 \mathrm{ml}$ のカルシウム塩とマグ ネシウム塩を含んだ phosphate buffered saline (PBS)
で室温で 3 回洗浄し，反応液として $\left.{ }^{125} \mathrm{I}\right]-\mathrm{NaI}$ (Amersham, IMS-30）を最終濃度が $1 \mathrm{mCi} / \mathrm{ml}$ になるように調 整した $\mathrm{PBS}$ を $0.2 \mathrm{ml}$ 加える. ラクトパーオキシダーゼ (Boehringer Mannheim, 107-174) および過酸化水素水 を最終濃度がそれぞれ $35 \mu \mathrm{g} / \mathrm{ml}$ 拈よび $0.00075 \%$ にな るように加えれば反応が開始するので，室温に 3 分間放 置する. 最後に，反応液を除き，PBS で 3 回洗浄するこ とによって反応を停止する．多数の 検体を同時に 標識 するには, $35 \mathrm{~mm}$ の培養血の代わりに, 培養面積が 2 $\mathrm{cm}^{2}$ の Linbro plateを利用してもよく，この場合は $0.075 \sim 0.1 \mathrm{ml}$ の反応液を用いる.

以上, 細胞表面に特異的な標識法の一例を示したが, これらの方法に共通な問題点として, 次の 2 つを指摘し たい，第一は，培養系に死細胞が多く含まれているとき の問題である.つまり，この場合には細胞質のタンパク 質が標識されることになる．標識反応が表面に特異的で あることを判断する一つの基準として，細胞骨格を構成 するチューブリンやアクチンが標識試薬と反応していな いことを確認するようにしている，第二の問題点は，紼 胞に付着した培地由来の血清タンパク質が標識され，こ れが細胞表面タンパク質と誤認されることである．この 問題の解決法の一つとして，筆者らは細胞表面タンパク 質のうちで，特に integral membrane protein に属す る成分を分析する方法をとっている，すなわち，膜タン パク質は次の 2 種，すなわち形質膜の脂質二重層と疎水 結合で強固に結合した integral membrane protein, お゙ よび膜表面とイオン結合などで相互作用しているが脂質 二重層とは直接の結合を持たない peripheral membrane protein に分類されており(10)，後者はある条件のもと で可溶化が 可能である(11).たとえば，標識が 完了した 培養㿼を氷冷し，それに $1 \mathrm{ml} の 0.1 \mathrm{~N} \mathrm{NaOH}$ を加え， $20,000 \mathrm{~g}, 1$ 時間の遠心分離で膜成分を沈渣として得る と, peripheral membrane protein や血清タンパク質 を可溶画分に除くことができる. integral membrane protein を含んだ沈椬は遠心分離法で一度水洗し, 分析 に供する.

糖タンパク質を・細胞の代謝能を利用して標識する実験 例は以下のと拉りである(8).

$\mathrm{CHO}$ 細胞を初密度が $2.5 \times 10^{5}$ 細胞 $/ \mathrm{cm}^{2}$ になるよう に直径 $100 \mathrm{~mm}$ の培養血に播き, 24 時間後に $1-\left[{ }^{14} \mathrm{C}\right]-$ グルュサミン (New England Nuclear, NEC-193 X)を 
$4 \mu \mathrm{Ci} / \mathrm{ml}$ に含んだ培地 $8 \mathrm{ml}$ と交換 する.さらに 24 時間後に, 上述の $0.1 \mathrm{~N} \mathrm{NaOH}$ による抽出法で形質膜 を含む沈渣を調製し， $\left[{ }^{14} \mathrm{C}\right]-ク ゙ ル コ$ サミンで標識された integral membrane protein の分析を行なう.こ

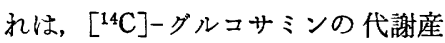
物によって多くの細胞質の糖鎖を含 まないタンパク質が標識されるの でこれを除去することを目的とし ている.

Peripheral membrane protein $の$ 同定は難しい問題であるが，筆者ら は $\left[{ }^{125} \mathrm{I}\right]-\mathrm{NaI}$ で標識した細胞から 形質膜を調製することによってある 程度の成果を収めている、詳細は文 献(8)を参照されたい。

\section{2. ポリアクリルアミドゲルの}

\section{組成と試薬の調製法}

第一次元目に用いるポリアクリル アミドゲルの組成を表 1に示した. 第二次元目は基本的には Laemmli の系(12)と同じで, これをスラブゲル
表 1 第一次元電気泳動ゲルの諸成分の最終濃度

\begin{tabular}{|c|c|c|c|c|c|c|c|}
\hline & 緩 衝 液 & $\mathrm{pH}^{\mathrm{a}}$ & $\begin{array}{l}\mathrm{Acr}^{\mathrm{b}} \\
(\%)\end{array}$ & $\begin{array}{l}\text { Bis } \\
(\%)\end{array}$ & $\begin{array}{l}\text { SDS } \\
(\%)\end{array}$ & $\begin{array}{c}\text { Triton } \\
(\%)\end{array}$ & $\begin{array}{c}\text { 尿素 } \\
(\mathrm{M})\end{array}$ \\
\hline 陰極用緩衝液 & グリシン, $50 \mathrm{~mm}$ & $10.5(\mathrm{NaOH})$ & & & 0.1 & 0.3 & \\
\hline 濃 縮 ゲル & Tris, $125 \mathrm{~mm}$ & $6.8(\mathrm{HCl})$ & 2.5 & 0.25 & & 1.2 & \\
\hline 分離 ゲル & Tris, $375 \mathrm{~mm}$ & $9.0(\mathrm{HCl})$ & 2.2 & 0.22 & 0.1 & 0.3 & 9 \\
\hline 陽極用緩衝液 & Tris, $375 \mathrm{~mm}$ & $9.0(\mathrm{HCl})$ & & & 0.1 & 0.3 & \\
\hline
\end{tabular}

a. $\mathrm{pH}$ 調整に用いる試楽をカッコ内に示した.

b. 試薬名は以下のように略した. Acr：アクリルアミド, Bis : $N, N^{\prime}$-メチレンビ スアクリルアミド, SDS : ドデシル硫酸ナトリウム, Triton : Triton CF 10, Tris : トリス（ヒドロキシメチル）アミノメタン

\section{表 2 ゲル用の原液の調製法 ${ }^{\mathrm{a}}$}

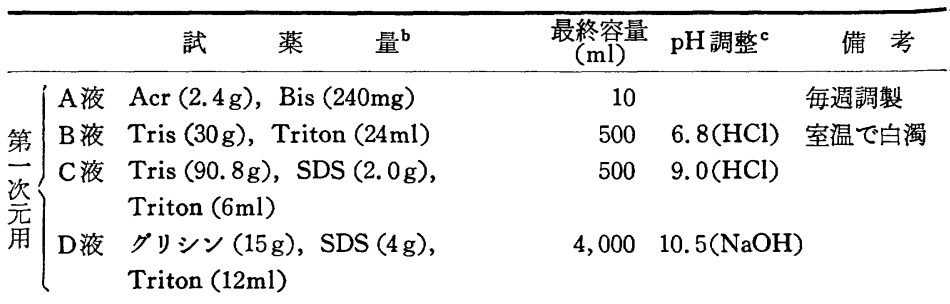

\begin{tabular}{|c|c|c|c|c|c|}
\hline & E液 & Acr $(150 \mathrm{~g})$, Bis $(3.9 \mathrm{~g})$ & 500 & & 数力月安定 \\
\hline \multirow[b]{2}{*}{ 第 } & $\mathrm{F}$ 液 & Tris $(30 \mathrm{~g}), \operatorname{SDS}(2 \mathrm{~g})$ & 500 & $6.8(\mathrm{HCl})$ & \\
\hline & G 液 & Tris $(90.8 \mathrm{~g}), \operatorname{SDS}(2 \mathrm{~g})$ & 500 & $8.8(\mathrm{HCl})$ & \\
\hline 恣 & $\mathrm{H}$ 液 & 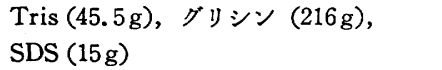 & 15,000 & 不 要 & $\begin{array}{l}\mathrm{pH} \text { 調整をし } \\
\text { てはならない }\end{array}$ \\
\hline & $I$ 液 ${ }^{d}$ & $\begin{array}{l}\text { アガロース }(15 \mathrm{~g}), \operatorname{SDS}(10 \mathrm{~g}), \\
0.1 \% \text { ブロムフェノールブルー }(12.5 \mathrm{ml})\end{array}$ & 500 & & \\
\hline
\end{tabular}

a. H液は室温に保存するが，それ以外は冷暗所に保存する.

b. 試薬名の略名については, 表 1 の脚註を参照されたい.

c. $\mathrm{pH}$ 調整に用いる試薬をカッコ内に示した.

d. 熱時に $500 \mathrm{ml}$ のH液で溶解し, $5 \sim 10 \mathrm{ml}$ を密栓試験管に分注し, 冷暗所に保 存する.
として利用したので, 組成表は割愛した.アクリルアミ

ド溶液や緩衝液などの原液の処法は表 2 に示した。

使用した主な試薬の出所は以下のとおりである。アク リルアミドとしては現在は Bio Rad 製の試薬 (No. 1610101）を用いているが，筆者らは長年にわたって Eastman Kodak 製の試薬（No. 5521）を醀酸エチルで 2 度 再結晶化したものを用いて充分満足できる結果を得た. この場合, 酢酸エチル $1 l$ にアクリルアミド $500 \mathrm{~g}$ を熱 時溶解し, 活性炭で脱色した濾液から再結晶するように する．その他の試薬は， $N, N^{\prime}$-メチレンビスアクリルア ミド: Eastman Kodak 製 (No. 8383), トリス（ヒドロ キシメチル) アミノメタン: 半井製 (No. 354-06), Triton CF-10: Rohm and Haas 製 (Sigma より入手), SDS : 半井製 (No. 316-07)，アガロース：半井製 (No. 01102) である.

\section{3. 第一次元ゲルの作製}

\section{1）電気泳動装置}

第一次元目の泳動は一定温度で行ならため, ジャケッ ト付きの Hoefer 製 Model DE-102 を用いている. 試料 の全タンパク質量が $300 \mu \mathrm{g}$ 以下の場合は内径 $2 \mathrm{~mm}$, 外径 $4 \mathrm{~mm}$, タンパク質量がそれ 以上の 場合は内径 4 $\mathrm{mm}$, 外径 $6 \mathrm{~mm}$ のガラス管を用いる.ガラス管の全長 は $17 \mathrm{~cm}$ とし，下から $11 \mathrm{~cm}$ と $14 \mathrm{~cm}$ のころに印 をつけ，下端をパラフィルムで閉じてゲル作製台（Bio Rad 製 Model 215) に立てる.この作製台全体を $18 \pm 1$ ${ }^{\circ} \mathrm{C}$ の水を入れた水浴に漬け，ガラス管の下端から少な くとも $15 \mathrm{~cm}$ は水に漬っているよらにする.これは, 種 種の条件下でゲルを作製した結果，第一次元目のゲルを 作製する温度を一定に保つことが大切であることがわか ったためで，使用直前まで所定の温度に保っておく． 
表 3 第一次元ゲルの調製法 ${ }^{\mathrm{a}}$

\begin{tabular}{|c|c|c|}
\hline 試薬 & 濃縮ゲル & 分離ゲル \\
\hline $\mathrm{A}$ 液 & $0.53 \mathrm{ml}$ & $0.91 \mathrm{ml}$ \\
\hline $\mathrm{B}$ 液 & $1.25 \mathrm{ml}$ & \\
\hline C液 & & $2.5 \mathrm{ml}$ \\
\hline 45\%グリセリン & $1.11 \mathrm{ml}$ & \\
\hline 尿素 & & $5.4 \mathrm{~g}$ \\
\hline 水 & $2.08 \mathrm{ml}$ & $2.7 \mathrm{ml}$ \\
\hline TEMED & $1 \mu l$ & $12.5 \mu \mathrm{l}$ \\
\hline 10\%過硫酸アン & $20 \mu 1$ & $10 \mu \mathrm{l}$ \\
\hline モニウム水溶液 & & \\
\hline
\end{tabular}

a. 内径 $2 \mathrm{~mm}$ のガラス管を用いて 12 本のゲルを作るとき の混合量を示した.

\section{2）ゲルの作製}

内径 $2 \mathrm{~mm}$ のガラス管を用いて 12 本のゲルを作製す るには，表了に従って溶液を調製する，A液から $N, N$, $N^{\prime}, N^{\prime}$-テトラメチルエチレンジアミン (TEMED) まで の試薬を順次三角フラスコに加える．分離ゲルに関して は，温めて尿素を溶解するが，温めすぎたり，温浴中に 放置したりしないように注意する。つぎに，真空デシヶ ーターなどを用いて脱気し, 約 1 時間 $18 \pm 1^{\circ} \mathrm{C}$ の水浴中 で温度を平衡化してから使用する。

所定容量の過硫酸アンモニウム溶液を両ゲル溶液に加 えてから、これを手早くガラス管に注入する。まず，分 離ゲル溶液を下から $11 \mathrm{~cm}$ のところまで入れ，ただら

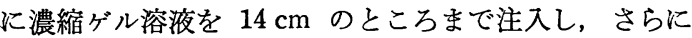
その表面に約 $50 \mu \mathrm{l}$ の 4 倍稀釈したB液を積層する. 分 離ゲル溶液を細いガラス管に 注入するには，20 G の注 射針の先を平坦にして内径 $0.8 \mathrm{~mm}$, 外径 $1.4 \mathrm{~mm}$ のポ リエチレン細管を接続したものを用いるのが便利でめ る.ゲル化は約 30 分で開始するが， 2 時間は静置して から使用する．しかし，4〜5時間以上たったゲルは使 用しない。

\section{4. 第二次元ゲルの作製}

\section{1）電気泳動装置}

スラブゲル電気泳動装置はいずれも Studier ${ }^{(13)}$ の方 法を踏襲している．筆者らは，幅 $16.25 \mathrm{~cm}$, 高さ 21.25 $\mathrm{cm}$ ガラス板を用いているので，それに応じた装置を作 り使用している. 二次元電気泳動法では, O’Farrell( ${ }^{(3)} の$ 考案による特殊加工を施したガラス板を用いる 例が多 い. 筆者らもこの方法でおおむね満足のゆく結果を得て いるが，分子量 15 万以上の細胞表面タンパク質の分離
表 4 第二次元ゲルの調製法 ${ }^{\mathrm{a}}$

\begin{tabular}{|c|c|c|}
\hline 試 & 濃縮ゲル゙ & 分離ゲル \\
\hline $\mathrm{E}$ 液 & $6 \mathrm{ml}$ & $24 \mathrm{ml}$ \\
\hline $\mathrm{F}$ 液 & $15 \mathrm{ml}$ & \\
\hline G 液 & & $36 \mathrm{ml}$ \\
\hline 45\%グリセリン & $6.6 \mathrm{ml}$ & $32 \mathrm{ml}$ \\
\hline 水 & $32.4 \mathrm{ml}$ & $51 \mathrm{ml}$ \\
\hline TEMED & $30 \mu \mathrm{l}$ & $72 \mu 1$ \\
\hline $\begin{array}{l}10 \% \text { 過硫酸アン } \\
\text { モニウム水溶液 }\end{array}$ & $90 \mu \mathrm{l}$ & $360 \mu \mathrm{l}$ \\
\hline
\end{tabular}

a . 6 枚のスラブゲルを用いる混合量を示した．濃縮ゲル表 面の厚みは $2 \mathrm{~mm}$ である

に問題が残った.この原因が，ガラス板の構造にあるこ とがわかったので，これを改良した新しい装置を考案し た(14).すなわち, ガラス板の一部をわずか沉曲げるので ある.こうすることによって，濃縮ゲルの表面の厚みは 最高 $4 \mathrm{~mm}$ まで可能であるが, 下に向からほどゲルは次 第に薄くなり，分離ゲルは $0.79 \mathrm{~mm}$ (1/32 インチ) の均 一な厚みの平板となっている。最近，これに類似した装 置が市販されている（和科盛製）が，筆者らのものとは 大きさや使用法に関して若干の違いがあるようである. 細胞表面タンパク質の分析に関しては，上のような装置 が最良と考兄るので，本稿ではこの方法に沿って分析法 を紹介する．また，筆者らはこの種の装置の製造方法に 関して，読者からの相談に充分応じてゆきたいと考えて いる.

\section{2）、ゲルの作製}

12 枚のスラブゲルを作製するには，分離ゲル溶液を $288 \mathrm{ml}$ 調製する.濃縮ゲル溶液に関しては, 表面の厚み を $2 \mathrm{~mm}$ とする場合は $120 \mathrm{ml}$ ，また $4 \mathrm{~mm}$ とする場合 は $180 \mathrm{ml}$ を準備する，試薬の混合量の一例を表 4 亿示 した.

E液から TEMED までの試薬を混合し，脱気してか ら氷冷する.これは 6 枚とか 12 枚のゲルを同時注入 するには 10〜20 分を要するので，反応を若干おさえる 必要があるためである. 所定量の過硫酸アンモニウム溶 液を分離ゲル溶液に加えて，組み立てられたガラス板の 中に底辺より $13 \mathrm{~cm}$ のところまで注入する.つぎに, 過 硫酸アンモニウム溶液を濃縮ゲル溶液に加えて, 分離ゲ ル溶液の上に積層し, 底辺より $16.5 \mathrm{~cm}$ のところまで 満たすと、ゲル表面の厚みは $2 \mathrm{~mm}$ となるはずである. 濃縮ゲル溶液の表面を水で 4 倍に稀釈した F 液でおおう 
が、これにはアイロン用の霧吹きを利用するのが便利で ある.ゲル化は 45 分ほどで始をるが，最低 2 時間は放 置してから使用する．第二次元目のゲルは使用前日に作 製しておいてもよいので，この場合はポリ袋などでおお い,ゲルが乾かないようにして报く。

\section{5. 電気泳動操作法}

\section{1）第一次元電気泳動の実施}

膜タンパク質の試料は多くの場合，沈澱物として得ら れるので, SDS を含んだ緩衝液を用いて，100ㄷ，3 分 間加熱してタンパク質を溶解する．冷却後, Beckman 製 Airfuge を用いて室温で約 1 時間, $100,000 \mathrm{~g}$ で遠心 分離を行ない，その上清液を用いる。試薬調製用の緩 衝液は，Tris $125 \mathrm{~mm}, \quad$ SDS $3 \%$ ，グリセリン 10\%，

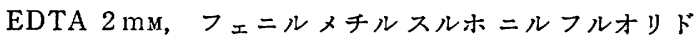
(Cal Biochem 製) $2 \mathrm{~mm}, N$-エチルマレイミド $1 \mathrm{~mm}$, ヨードアセトアミド $1 \mathrm{~mm}$, ブロムフェノールブルー

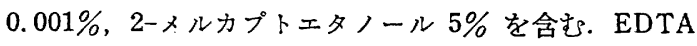
以下 4 種類の試薬はタンパク質分解酵素の阻害剤と考兄 られている.

第一次元目のゲルを電気泳動装置にとりつけ，下槽を $18^{\circ} \mathrm{C}$ に保った電極用緩衝液 (表 1 参照)で分離ゲルがす っかり漬かるまで満たし，ジャケットには $18^{\circ} \mathrm{C}$ の恒温 水を循環させる．上槽には $4^{\circ} \mathrm{C}$ に保った電極用緩衝液 を，ガラス管の端を $5 \mathrm{~mm}$ ほど残すぐらいまで加える. 内径 $2 \mathrm{~mm}$ のガラス管を用いた場合は最高 $60 \mu \mathrm{l}$, 内径 $4 \mathrm{~mm}$ のガラス管の場合は $240 \mu \mathrm{l}$ までの試料を添加でき

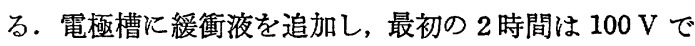
定電圧電気泳動を行ならと, ブロムフェノールブルーは 㴗縮ゲルと分離ゲルの 界面に到達する．さらに約 1 時 間， $500 \mathrm{~V}$ の定電圧で泳動を継続し，色素のバンドが下 端に達するのを待って泳動を終了する，下槽の電極用緩 衝液は，冷所に保存すれば 5 回は再使用できる。

\section{2）第二次元ゲルの前処理}

第一次元電気泳動を開始するのと同時に，第二次元目 のスラブゲルの上の緩衝液を取り除き，その代わりに， 2-メルカプトエタノールを $5 \%$ に含んだ同じ緩衝液を 注ぎ込む.これは第一次元目の泳動中にタンパク質が酸 化を受ける可能性があるので，これを再還元するためで ある.これと同じ目的で O'Farrell(3) は，第一次元目の
ゲルをガラス管から取り出し，これを還元剤を含んだ緩 衝液中で振とうしているが，この方法では抎散に伴いタ ンパク質が抽出されたり，分離が悪くなったりする欠点 がある．筆者らの方法は，これらの点をほぼ完全に改良 していると考えている.この改良法は，ガラス板を曲げ たために濃縮ゲルの表面積が増したことによって可能と なった.

\section{3）第二次元電気泳動の実施}

第一次元目のゲルは,ゲルとガラス管壁の間に注射器 を用いて水を注入することによって比較的簡単に取り出 すことができる.この操作には，10 $\mathrm{ml}$ の注射筒と，長 さ $9 \mathrm{~cm}$ の $25 \mathrm{G}$ のスパイナル針を用いるのが便利であ る. 取り出したゲルをピンセットですくい，過鄱の水を 除いてから長さ $13 \mathrm{~cm}$ ほどの適当なプラスチック板の上 でゲルをまっすぐ伸ばす. 第二次元ゲルの上の 2-メル カプトエタノールを含んだ緩衝液を充分取り除き，第一 次元ゲルをプラスチック板からすべらせるようにして濃 縮ゲルの上に移す．つぎに，このガラス板のセットをス ラブゲル電気泳動装置に取りつける.このままでは，第 一次元ゲルがただ乗っているだけなので，これを固定す るために熱溶解した I 液をゲルの上に 約 $2 \mathrm{~mm}$ の厚さ の層になるように静かに注入する. 冷却とともにアガロ 一スはゲル化し，第一次元ゲルは濃縮ゲルの表面に直に 接した格好で固定されることになる。電極槽に緩衝液を 加兄, 定電流電気泳動を行ならが, 筆者らはゲル 1 枚当 り $5 \mathrm{~mA}$ で 16 時間泳動し,ささらに $15 \mathrm{~mA}$ で色素が下 端に 達するまで泳動している. 電源としては, 出力が

\section{表 5 二次元電気泳動の時間配分の一例}

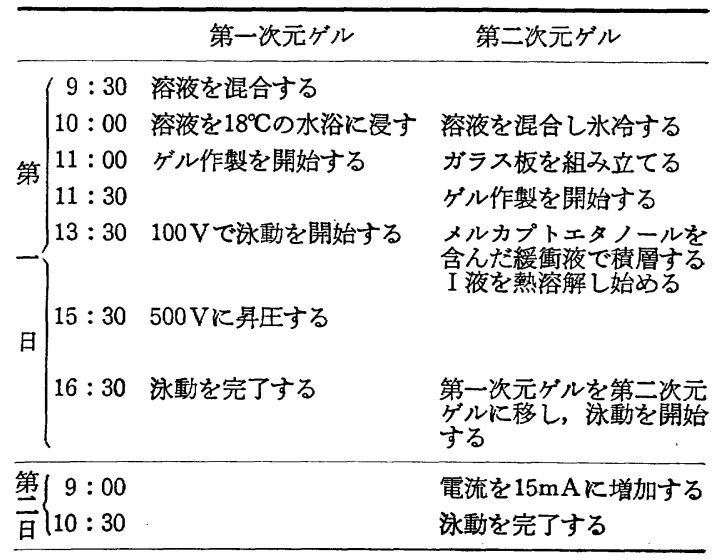


$500 \mathrm{~V}, 400 \mathrm{~mA}$ 程度の装置を用いる と，24枚までのスラブゲルを並列 に接続して同時分析することが可能 である. 二次元電気泳動の時間配分 の一例を表 5 に示した。

4) ゲルの固定, 染色, オートラ ジオグラフィー

取り出したスラブゲルは，0.01\% のクーマシーブルーR 250 を含むエ タノール $50 \%$, 酢酸 $10 \%$ の混合液 の中で約 1 時間振とらし, 染色す る. 脱色にはエタノール 10\%, 酢酸 $5 \%$ の混合液を約 $55^{\circ} \mathrm{C}$ に温めて使 用する。

その後の処理は, 細胞表面タンパ ク質をどのアイソトープを用いて標 識したかによって異なる、たとえ ば, ${ }^{125} \mathrm{I}$ や ${ }^{131} \mathrm{I}$ を用いた場合には, ゲルをそのまま濾紙の上で乾燥させ ればよい。乾燥には, Bio Rad 製 Model 224 をはじめとして多くの装 置が市販されている. ${ }^{125} \mathrm{I}$ や ${ }^{131} \mathrm{I}$ の 感光には, $-70^{\circ} \mathrm{C}$ で増感スクリーン を使用すると感光時間を短縮するこ とができる. DuPont 製の Cronex

Plus や Lightening Plus を用いたときには, 室温で増感 スクリーンを使わなかったときに比べて, ${ }^{125} \mathrm{I}$ では約 10 倍, ${ }^{131}$ I では約 3 倍の感光速度の増加が得られる. 一方, タンパク質を ${ }^{3} \mathrm{H},{ }^{14} \mathrm{C},{ }^{35} \mathrm{~S}$ などで標識したときには, Bonner \& Laskey ${ }^{(15)}$ の考案になるフルオログラフィー 法によって感光速度を増すことができる. その他に、サ リチル酸ナトリウムを用いたり ${ }^{(16)}$, 市販のフルオログラ フィー試薬 (New England Nuclear 製, EN ${ }^{3}$ HANCE) を用いても同様の増感効果が得られる.

\section{6. 分 析 例}

オートラジオグラフィーによって検出される各成分 は, 冒頭に述べたような種々の細胞の機能と関係がある はずであるが，これを明らかにすることが今後の課題と なる. 分化, 癌化, 転形に伴う細胞表面タンパク質の変 用いた.
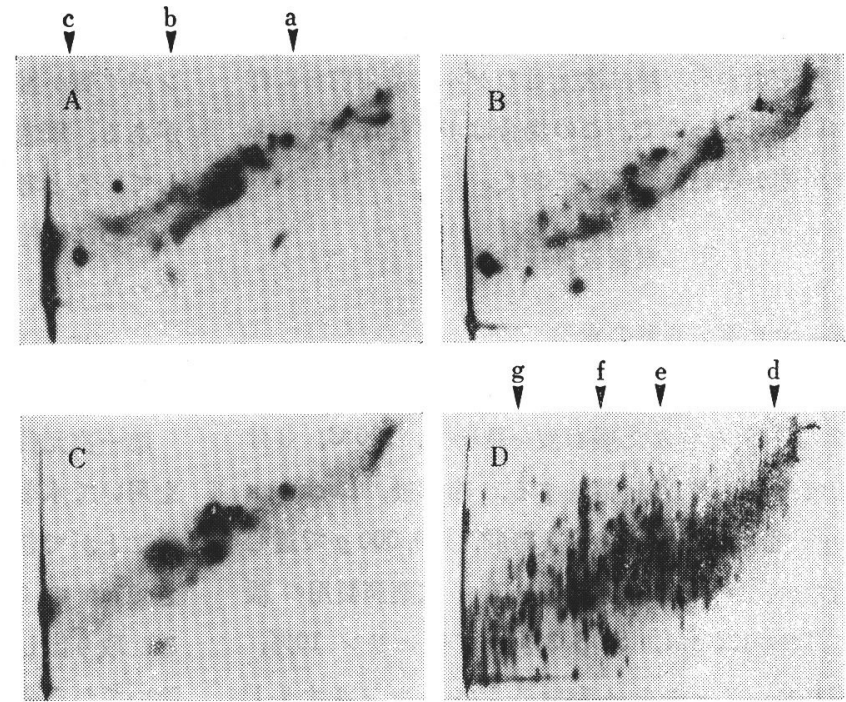

二次元電気泳動法によるタンパク質の分析

分離の原点は各図の右上端に相当し，第一次元目 (1D) および第二次目 (2D) の泳動方向は矢印で示した. A，B，Cに示した例では，第二次元目電気泳動に アクリルアミドを $5 \%$ 含も SDS ゲルを用い，Dの例ではアクリルアミド含量 $7.5 \%$ SDS ゲルを用いた. 図の上に矢印で示したおおよその分子量領域は 次のとおりである. a : 200,000, b : 100,000, c : 55,000, d : 250,000, e : 90,000 , f : 65,000 , g: 28,000 .

A : ヒトのフィブロサルューマ, MB-8387 株の細胞表面タンパク質. [ $\left.{ }^{125} \mathrm{I}\right]-$ 標識法を用いた。

標識法を用いた.

$\mathrm{C}:$ : トの肺癌，A-549 株の細胞表面タンパク質. [131 I]-NaI による標識法を オニンを培地に加え, 細胞を 24 時間培養することによって, 全タンパク 質を標識した.

化を，ヒトおよびげっ歯類の 細胞株を用いて 調べた結 果, これらのいずれの現象とも関係がある 1 つの細胞表 面タンパク質を発見したが，これに関しては別途に報告 した (2).ここでは, 癌細胞が持つ特異的な表面タンパク 質に注目し，ヒトのフィプロサルコーマ,メラノーマお。 よび肺癌の細胞の分析例を図に示した. 腫瘍特異抗原の 存在に関しては, 長年, 免疫学的探索が行なわれてお り, その結論は必ずしも肯定的でない, 一方, 図の分析 例では癌細胞による違いがかなりはっきりとわかり，特 異抗原があるのではないかといら疑問を抱かせる，この ような問題を追求するに当って, 従来の方法と, 本稿に 紹介した，どちらかと言えば化学分析的手法を併用する のが有効であると考劣る。

図の分析例では, 細胞表面タンパク質が二次元ゲルの 対角線の近傍に分布する，いわゆる diagonal effect が 
見られこえが分離の限界となっている。一方，図- $\mathrm{d} に$ 示した全細胞タンパク質の分析結果では, タンパク質の スポットが二次元ゲルのすみずみまで湟は均等に分散し $\tau$ ，比較的理想に近い分離が得られている．これは，筆 者らが，細胞表面タンパク質の分析之同時に，細胞質タ ンパク質ももれなく分析する方法を開発しょうとしたた めに，疎水性や糖鎖構造に関して共通点の多い細胞表面 タンパク質がゲル上の限られた範囲に分布する結果にな ったものと思われる．第一次元ゲルによる分離は，ゲル 作製や分析時の温度，および，分離ゲルの $\mathrm{pH}$ やデター ジェント組成によって変化することがわかっているの で(1)，目的に応じた改良を加えて使用していただきた W.

\section{文献}

1) M. Imada \& N. Sueoka : Biochim. Biophys. Acta, 625, 179 (1980).

お知らせ

\section{第14回日本脈管作動物質研究会}

特別講演 1 . 血管壁の構造 : 微小血管を中心として・愛媛大 学医学部 上原康生, 2.アンギオテンシン系の生 化学・愛媛大学医学部 国府達郎

\section{日 時: 昭和 60年 2 月 8 日（金） \\ 会場 : 愛媛県医師会医学研修所 松山市三番町 4 丁目5-3 0899-43-7582 \\ 送付書類：(参加および一般演題申し込み)：}

1）参加者名簿

2) 一般演題申込用紙

3）受領証 (40円切手貼付の上，住所 · 氏名・演題名を明 記して下さい)

4）演題抄録（所定の用紙に，タイプで打ち込んで下さい. 写真印刷に致します)

5）演題抄録コピー(黒) 2 部

6）申込締切 昭和59年12月10日(月)必着

一般演題発表形式 :

1）発表は口頭で，口演時間10分前後，討論 5 分を予定し て㧍りす。.

2）スライドはライカ版とし，1題10枚以内にお願い致し ます.プロジェクターは 1 台です。

会 費 :

会費 5,000 円（会誌「血管」購読料を含む）は，当日 会場にて申し受けます。

連絡先および送付先：

テ791-02 愛媛県温泉郡重信町大字志津川

愛媛大学医学部第一外科

8 0899-64-5111 (内線 2134)

第14回日本脈管作動物質研究会 事務局 大串直太
2) 今田 勝: 蛋白質核酸醅素, 28, 1397 (1983).

3) P. H. O'Farrell : J. Biol. Chem., 250, 4007 (1975).

4) 佐々木輝捷：生体の科学, 31, 436 (1980).

5) A. L. Hubbard \& Z.A.Cohn : J.Cell Biol., 55, 390 (1972).

6) C. G. Gahmberg \& S. Hakomori : J. Biol. Chem., 248, 4311 (1973).

7) D. A.Sears, C.F. Reed \& R.W. Helmkamp : Biochim. Biophys. Acta, 233, 716 (1971).

8) S.Imada \& M.Imada : J.Biol. Chem., 257, 9108 (1982).

9) M. Imada, P. Hsieh \& N.Sueoka : Biochim. Biophys. Acta, 507, 459 (1978).

10) S. J.Singer : in "Structure and Function of Biological Membranes”, Vol.2, ed. by L.A. Manson, Plenum Press, New York, 1971, p. 105.

11) T.L.Steck \& J.Yu : J.Supramol. Struct., 1, 220 (1973).

12) U. K. Laemmli : Nature, 227, 680 (1970).

13) F. W.Studier : J. Mol. Biol., 79, 237 (1973).

14) M. Imada : Anal. Biochem., 89, 292 (1978).

15) W. M. Bonner \& R. A. Laskey : Eur. J. Biochem., 46, 83 (1974).

16) J.P. Chamberlin : Anal. Biochem., 98, 132 (1979).

\section{教官公募}

\section{香川大学農学部園芸学科応用昆虫学講座助手}

上記教官を公募しております. 御関心のある方は, 下記に直 接お問い合わせ下さい（ただし，昭和 32 年 4 月 2 日以降生れの 人). 提出書類の締切は，昭和59年12月25日（火）必着です.

干761-07 香川県木田郡三木町池戸2393

香川大学農学部応用昆虫学講座助手選考委員会

잉 (0878) 98-1411 (ex. 202)

お知らせ

\section{シンポジウム}

“Medical Application of Liposomes"

期 日：昭和59年12月14日〜16日

場 所：名古屋観光ホテル

オーガナイザー：G. Gregoriadis，Y. Nozawa， D. Papahadjopoulos, K. Yagi

講演予定者（アルファペット順）:

C. R. Alving (Washington), B. K. Bachhawat(Calcutta), J.D. Baldeschwieler (Pasadena), I. J. Fidler (Houston), G. Gregoriadis (London), K. Hashimoto (Sendai), H. Hauser (Zürich), K. Inoue (Tokyo), L. D. Leserman (Marseille), E. Mayhew (Buffalo), Y. Nagai (Tokyo), C. Nicolau (Orleans), Y. Nozawa (Gifu), G. Poste (Pennsylvania), G. Scherphof (Groningen), J. Sunamoto (Nagasaki), F.C.Szoka (San Francisco), T. Tadakuma (Tokyo), K. Yagi (Gifu), T. Yasuda (Tokyo)

参 加 費 : 10,000 円（懇親会費を含む）

連 絡 先: 岐阜県可児郡御嵩町八木記念パーク 応用生化学研究所 ₹505-01 \& (0574)-67-5500

会場の都合がありますのでハガキでお申し込み下さい（300 名で締切ります). 